\title{
Forms, places and processes: tracing geographies of architecture through design competitions. Introduction to the special issue
}

\section{Joris Van Wezemael, Fribourg/Switzerland}

\section{What is an architectural competition?} (Synonyms: design competitions, planning competitions)

An architectural competition can be regarded as a «site» marking the convergence of diverse interests (for example, those of the building industry, private investors and governmental institutions), findings from various fields of research (for example, structural analysis, sustainability and preservation order) and discourses from very diverse societal fields (relating, for example, to topics such as aesthetics, faimess/justice or profit). Indeed, it is this interdisciplinary aspect which allows an architectural competition to draw together different fields of actuality and to enable translations between them. An architectural competition may transform ambiguous societal and politically disputed problems into concrete building projects; it may replace open/ unsettled/unsolvable/dynamic clashes with solid building constructions, or more specifically, turn political disputes into what would seem to be «a-political» design problems (thereby leading to discussions about height of eaves, façade design, budget calculations or sustainability criteria). However, an architectural competition may also constitute a political event: it may «shape» public consciousness or public opinion, and it may enable a society to transcribe (or translate) its ideals and objectives into its built environment.

Against this background architectural competitions can be regarded as significant decision-making procedures within urban landscapes. They pave the way towards alternative urban future scenarios, acting as «sorting machines» whilst doing so; they move a given place from the most fixed form (a steel or concrete construction, a stonework or simply waste land) to the most fluid form (discourses, propositions, concepts, projects, drafts and ideas represented verbally, in texts, plans, models or electronically) and back again. This process of opening up (i.e. of producing ideas or creating a multitude of propositions) and narrowing down (i.e. of determining a solution and then putting forward that solution for actualisation into another fixed set of materials) can be seen as a key characteristic of the architectural competition.

Besides being a set of rules and routines, which are significantly being modified as we write, architectural competitions can also be viewed as an ancient form of tendering: a client asks for a variety of propositions with regard to a given problem, (s)he evaluates the entries and picks the best. But is it really that simple?

Whenever public organisations spend money in the building sector, they are bound to national and international tendering rules and regulations. At the same time, the building sector plays an important role in shaping our cities - and our lives. The building sector not only reflects political, economical and juridical decisions but also gives form to trends in architecture, planning and urbanism. Thus, the processes of selection, which are generally referred to as public procurement processes, are by their nature a platform that brings together heterogeneous actors and produces different procedural formations. The question is how research on architectural competitions can inform (urban and cultural) geography.

\section{Places without a form?}

Probably inspired by macro-anthropological theory that, since the late 1980 s, viewed cultural forms (including ideas, practices or objects) as the product of an often complex intersection of different types of flows (images, capital, people; see, for instance, ApPadurai 1996), DoreEN MASSEY redefined place as an intersection of networks: a horizontal, open phenomenon versus place as a vertical (historically shaped), bounded and homogeneous entity. At the same time, the German notion of «doing geography» («Geographie machen» in a WERLENIAN tradition) has led to the focus on processes of appropriation of space and on «space» as a (formal-classificatory) dimension in action («Raumbezug»). With both the «relational turn» in Anglo-Saxon human geography (see, for example, Amin 2002, 2004; MAssey 1999, 2005) and the social constructivist view of social geography in the German speaking world (see WERLEN 1992 and others), mainstream geography has left (geo-) deterministic approaches for good (or so it can be hoped).

Whereas the above mentioned bodies of literature continue to have an impact on contemporary (urban) geography, it has to be agreed with GUGGENHEIM and SöDERSTRÖM (2009) that places in Geography are rather undefined as built forms. This might be one reason why the (rare) debates of geographers about urban quality are generally rather low-brow. However, does aesthetics belong in the realm of urbanists and architects alone? Is built form not relevant to the notion of (urban) landscapes as cultural products? How is the urban texture produced, and what can be 
learnt from its study with regard to the relation of the political, the economic, the aesthetic, and the material? How are political discourses or administrative routines connected to the transformation of cityscapes?

These questions, it seems, are becoming increasingly relevant as a number of discourses (such as (neoliberal) notions of market-efficiency and transparency, or the mainstreaming of (ecological) sustainability as an unquestionable truth) colonize every corner of both public and academic discourse. Is it in 2011 politically incorrect to mention that global warming or climate change adaptation are not the only problems that the (many) futures of cities face? Is it acceptable to question the goal of transparency in public markets in favour of more scope for design, or a project that still attracts attention 300 years from now (but that may not be in line with current budget restrictions of a municipality)? As an academic I am deeply sceptical about generalizing discourses (see above) as they subjugate the multiplicity of the world (there will be a future beyond Masdar City!).

In order to critically deal with such questions it is important to highlight the relations between the semiotic and the material, or between the plane of the virtual and the strata of power. More precisely, the purposes of the articles in this issue of GEOGRAPHICA HeLvetica are to elaborate on how values and norms are transcribed into the built environment.

The collection of articles takes design competitions as an entry-point. The contributing authors that draw on examples from Greece, Canada, The Netherlands and Switzerland met at a workshop series within an organization science conference, «Constructions Matter», held on 5th-8th May 2010 at the Copenhagen Business School (CBS). Management scholars from the CBS invited a geographer to play the role of convenor in order to organize a workshop series on architectural competitions - not a bad start for what one could call a post-disciplinary field! The contributions in this special issue deal with procedural quality, changing public market regulations, the role and impact of (environmental) standards in jury based decision-making processes and with the transformation of global discourses into urban form. They reflect a small, but growing, international research community, which comprises of scholars from a range of disciplines, including architecture, art history, organization studies, geography and planning. The collection is complimented by an article from the field of housing studies.

In his contribution, JAN SiLberberger highlights key differences between evaluation and judgement as he tackles the relation of strategic development of a place with the scope for creativity, for unexpected proposals and for out-of-the-box thinking. In his empirical analysis he pays particular attention to the writing of the brief, which he views as an assemblage of wishes and restrictions. The link to the field of urban planning is made by an in-depth discussion of the pre-jury preparation of the competition programme on the basis of (strategic) development studies. How rigid, how exact should competition briefs be? When do they produce a mere «as-if» competition, and why? How can competing teams of planners grasp which notions should be taken almost literally, and how do they discover room for manoeuvre? SILbERBERGER argues that the writing of a competition programme should be seen as a process of organizing the competition's space of possibilities, and he argues for the process of translating a detailed request into a competition programme as a fourth process of judgement. Furthermore, his analysis allows for a positioning of competitions along a continuum from reducing the work of participating architects to the development of a nice form and nice facades for a project that is entirely determined right from the start at the one extreme of the axis, to searching for far-reaching and possibly unforeseen architectural propositions at the other extreme.

In their paper, Jean-Pierre Chupin and Carmela Cucuzzella share their concerned view of the widespread and often too uncritical use of environmental standards in the selection of projects in urban development. Elaborating on the key differences between technical rationality (as the foundation of evaluation models in environmental standards) and judgement (which demands controversy and different meaning in order to elaborate claims and move towards final decisions), they shed some light on the downside of the mainstreaming of sustainability. Indeed, the standardization of environmental standards on the grounds of «sustainability» as a meta-narrative about «the good» overpowers traditional criteria and fuels deterministic approaches. As a consequence, the authors argue, complex reality becomes fragmented, projects lose their coherence and the multidimensionality of urban landscapes becomes obscured. Drawing on JoHN ZEISEL's work, CHUPIN and CucuZZELLA provide a theoretical approach to understanding the recursive process in judgement by adopting a spiral succession of reflection and action.

LeentJe Volker and JuriaAn van Meel explore how the reorganization of public markets change the reproduction/transformation of urban landscapes. Whereas Silberberger and Chupin \& Cucuzzella discuss modes of decision-making at project level, VoLKER and van MEEL focus on the organization of public procurement as a system. However, like the articles discussed above, they too ask if quality is measurable and whether «quantitative» means «objective» when selecting a project or a partner? Their paper addresses 
a seminal shift from traditional design competitions towards tendering processes that are in line with $\mathrm{EU}$ public service contracting regulations. This implies a gradual transformation of the client who is supposed to carry both a cultural role and a responsibility towards the public. Does this transformation lead to more uniform and mediocre architecture, as many planners and designers fear? The authors present a careful analysis of the situation, highlighting the room for manoeuvre that architects have, the phases within EU public procurement processes that allow for «competition-culture», and they point out strategies and tactics which allow for a maximum of creativity within the (seemingly) «given» context of public markets.

SofIA PAISIOU presents a sensitive and highly symbolic series of four competitions for the New Acropolis Museum (NAM) in Athens. She stages design competitions as a place-making activity and thereby bridges conceptions of morpho-genesis from assemblage thinking (Deleuze 1994, Guattari 1984 or DeLanda 2002) with a geographical place-making tradition in the line of Doreen Massey $(1999,2005)$. Paisiou locates the dynamic processes of the genesis of form of the NAM in force fields of different tendencies and illustrates how a better understanding of place-making can be achieved. In the NAM project, what started off as a practical problem became a national issue and a way to shape a national identity by creating powerful bonds between the «progressive» past and the ongoing present. Competitions not only recombine various modes of knowledge, discursive arguments and materials of representation; they also set out a trajectory from imagination to realization. In a competition, laws, judgement processes, protagonists and outcomes «travel» by different means, localising in a unique way the global within the planning site. PAIsIou shows how political, practical and social demands that influenced the current decision and creation of NAM, changed over the four competitions. The author reads political issues such as the interrelation of cultural, economic and political aspirations, the entrance into the EU and the arrival of the free market as «grand narratives» in the sense of MASSEY (1999). This allows her to map the shift of the original focus from the creation of a new museum towards different trajectories, such as the re-assembling of global problems (pollution or the need for a bigger museum), and shows how they gain importance and relevance by becoming component parts of «assemblages», such as the «national identity» or «international cultural heritage of the Acropolis marbles».

The collection of papers on design competitions in this special topic issue thus discuss some of the manifold relations between form and process and sketch out a field that may be referred to as Geographies of Architecture. Design competitions are not only fascinating objects of research, rather, as the articles may illustrate, they offer a powerful epistemic vehicle that allows for a better understanding of how societal fields, such as the political, the economic and the aesthetic, are connected and how they produce a distinct materiality of place. Research on design competitions calls for interdisciplinarity as an epistemological necessity. They can be used as a means to produce knowledge about the joint becoming of objects that traditionally are neatly compartmentalized by (sub)disciplinary traditions. It is in this perspective that I believe that the articles summarized above can be most productive.

In a descriptive article, Isolde Brade, Carola Neugebauer and Konstantin Axenov address the postsoviet mobility of a number of pre-fabricated building types (large housing estates) in Russia (St. Petersburg) through a social space that considers reputation but also residential mobility of occupants according to their socio-economic status. In an analysis of both persistence and change of their relative position and role in the housing market, the authors embed the discussion in the field of socio-spatial segregation and thus link the changes in economic and symbolic attributes of housing types with urban development.

\section{References}

GUGGENHEIM, M. \& O. SöDERSTRÖM (2009): Re-shaping cities: how global mobility transforms architecture and urban form. - London, New York: Routledge.

Amin, A. (2002): Spatialities of globalisation. - In: Environment and Planning A, 34: 385-399.

Amin, A. (2004): Regions unbound: towards a new politics of place. - In: Geografiska Annaler, series B, 86,1: 33-44

AppaduraI, A. (1996): Modernity at large: cultural dimensions of globalization. - Minneapolis: University of Minnesota Press.

DELANDA, M. (2002): Intensive science and virtual philosophy. - London: Continuum.

Deleuze, G. (1994): Difference and repetition. London: Continuum.

GuATTARI, F. (1984): Molecular revolution: psychiatry and politics. - London: Penguin.

Massey, D. (2005): For space. - London: Sage.

Massey, D. (1999): Spaces of politics. - In: Human Geography Today: 358; http:/www.worldcat.org/title/ human-geography-today/ocld/40943522 30.1.2011.

WERLEN, B. (1992): Society, action and space: an alternative human geography. - London, New York: Routledge.

Prof. Dr. Joris Van Wezemael, Human Geography, Department of Geosciences, University of Fribourg, 4, chemin du Musée, CH-1700 Fribourg, Switzerland. e-mail: joris.vanwezemael@unifr.ch 